\title{
A Case of Angiotropic Large Cell Lymphoma Primarily Discovered in Biopsy Specimens from Liver and Bone Marrow
}

\author{
M. Kahvic a N.C. Nayak ${ }^{d}$ S. Mokhtar ${ }^{a}$ A.S. Dhamer ${ }^{b}$ \\ A.R.D. Luluc \\ Departments of a Pathology, ${ }^{\mathrm{b}} \mathrm{Haematology}$, and ${ }^{\mathrm{c}}$ Medicine, Al-Jahra Hospital, and \\ dDepartment of Pathology, Faculty of Medicine, Kuwait University, Kuwait
}

\section{Key Words}

Angiotropic large cell lymphoma .

High-grade non-Hodgkin's lymphoma •

Biopsy

\begin{abstract}
Objective and Importance: We describe an unusual site for angiotropic large cell lymphoma (ALCL) diagnosed from liver and bone marrow biopsy specimens. ALCL is a rare, multifocal, exclusively intravascular and generally fatal disorder of high-grade non-Hodgkin's lymphoma. Clinical Presentation: The patient, a 70-year-old woman, presented with hepatosplenomegaly, anaemia, and disturbed liver function tests. Conclusion: As far as we know, and according to the available literature, liver and bone marrow biopsies have never been reported as being primary sites of ALCL.
\end{abstract}

\begin{tabular}{ll}
\hline KARGER & (1) 1999 S. Karger AG, Basel \\
Fax +4161306 1234 $34-7571 / 99 / 0081-0069 \$ 17.50 / 0$ \\
$\begin{array}{l}\text { E-Mail karger@karger.ch } \\
\text { www.karger.com }\end{array}$ & $\begin{array}{l}\text { Accessible online at: } \\
\text { http://BioMedNet.com/karger }\end{array}$
\end{tabular}

\section{Introduction}

Angiotropic large cell lymphoma (ALCL) is a rare and generally fatal disorder of highgrade non-Hodgkin's lymphoma, characterized by multifocal, almost exclusively intravascular proliferation of large neoplastic lymphoid cells within the lumina of medium and small-sized vascular channels [1-17]. Since 1959, when it was originally described by Pfleger and Tappeiner [13] as 'systemic angioendotheliomatosis of the cutaneous blood vessels', for more than 37 years, this disorder was reported under different names describing the same disease. The majority (75-85\%) of reported cases showed primary involvement of the skin and central nervous system $[6,17]$. Other organs as primary sites of this neoplasm are rare, although when the disease advances it may often spread to different internal organs $[1,4-6,9,10,16]$. The liver and bone marrow can be occasionally in-
Dr. Mirza Kahvic

PO Box 28047

Safat (Kuwait) 


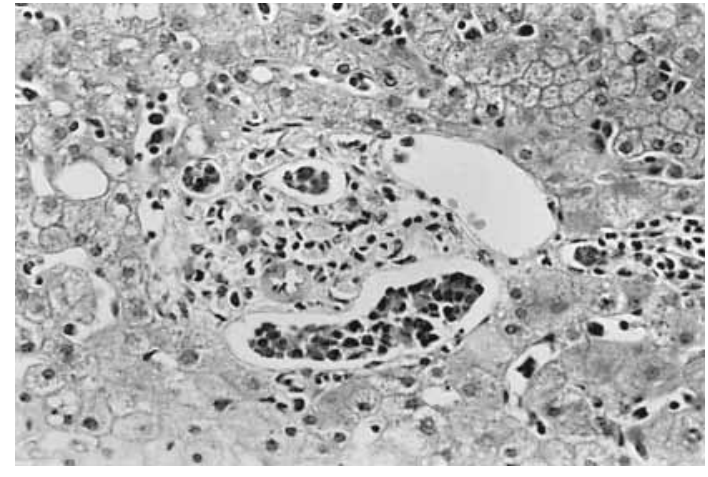

Fig. 1. The thin-walled vessels of the portal tract are partly occluded by neoplastic lymphoid cells.

volved, but all such cases are discovered at autopsy only $[1,4,9,10]$. In this report, we describe an unusual case of ALCL discovered in biopsy specimens from the liver and bone marrow.

\section{Case Report}

A 70-year-old woman was admitted at Al-Jahra Hospital in January 1993 with a 5 days' history of nausea and vomiting. On admission the patient was pale, feverish $\left(39^{\circ} \mathrm{C}\right)$ and had dry cough. Abdominal sonography showed hepatomegaly $(+++)$, splenomegaly $(++)$ and no lymph node enlargement. Chest examination revealed scattered rhonchi and bilateral basal crepitations. Chest radiography showed bilateral bronchiectasia, no suspicious masses and no hilar lymph node enlargement. Clinical examination of the heart, CNS and skin revealed no abnormality. The blood picture was WBCs $15.9 \times 10^{9} / 1$ (normal 3.6-9.6) with $68 \%$ neutrophils and $32 \%$ lymphocytes, RBCs $3.2 \times 10^{12} / 1$ (normal 4.2-5.4), Hb $9.6 \mathrm{~g} / \mathrm{dl}$ (normal 1216), ESR 98 and Hct ratio 30.5 (normal 37-47). The biochemistry results were as follows: albumin $25 \mathrm{~g} / 1$ (normal 35-55), T. Bil. 22 (normal 3-18), D. Bil. 4 (normal 0-4), AST 131 IU/1 (normal 10-45), ALP 180 IU/1 (normal 50-135), and LDL 1,605 IU/1 (normal 100-190). A week after admission and due to hepatosplenomegaly, disturbed liver function tests, and anaemia, clinicians decided to perform liver and bone marrow biopsies.

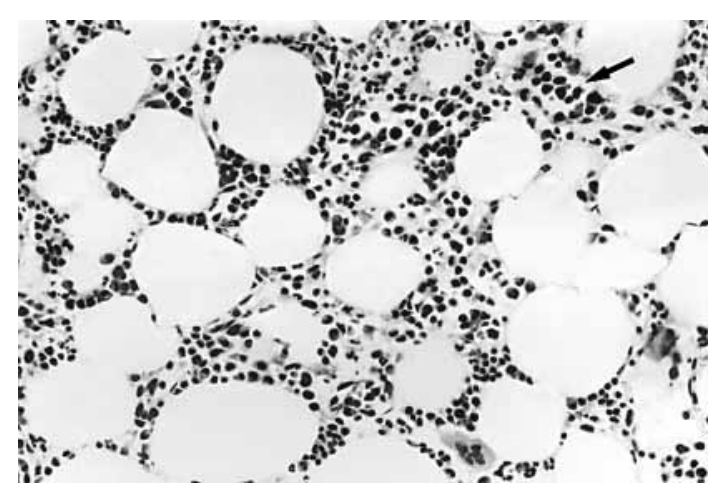

Fig. 2. Bone marrow interstitial capillary lumens contain neoplastic lymphoid cells (arrow).

Histopathological examination showed the following:

(1) The liver biopsy showed preserved hepatic architecture. The thin-walled vessels of the portal tracts were dilated and partly occluded by large noncohesive neoplastic lymphoid cells. These cells were pleomorphic and had hyperchromatic pleomorphic nuclei with relatively prominent nucleoli. In some vessels, few RBCs were seen around the malignant cells suggesting that these vessels were veins rather than lymphatics. In the adjacent sinusoids of the portal tracts, single malignant lymphoid cells were focally observed. The endothelial lining of the vessels showed no atypia. The hepatocytes showed no abnormality (fig. 1).

(2) The bone marrow biopsy revealed slight hypocellularity and dilated interstitial capillaries filled with the same neoplastic lymphoid cells as seen in the liver biopsy (fig. 2).

Immunohistopatholigical examination revealed:

Paraffin sections of the liver and bone marrow biopsies were used for our immunohistochemical study. DAKO EPOS antibodies and staining procedures were employed. The neoplastic cells stained strongly positive for both LCA (CD45) clone PD7/26 and clone 2B 11 code U7024 as well as B-cell (CD20) clone L26 code U7021. In contrast, staining for T-cell (CD45RO) clone UCHLI code M0742 and cytokeratin: CK wide-spectrum, polyclonal code Z0622; CK116 clone MNF116 code U7022; CK10/13 clone DEK 13 code M7003; CK HMW clone 34BE12 code M0630 and S-100 protein polyclonal code U0029 and factor VIII-related antigen clone F8/F86 code M0616 were all negative. 
Follow-Up. Twenty-five days after admission, the patient was transferred to the Kuwait Cancer Control Centre Hospital for chemotherapy. Three months later, she died at home. Unfortunately, the post-mortem was not performed.

\section{Discussion}

As mentioned, ALCL is a rare and unusual proliferation of large lymphoid neoplastic cells within the lumina of medium and smallsized vascular channels. In the past, there has been a controversy with regard to the origin of these neoplastic cells $[6,16]$. Originally described as being endothelial [13], these cells were recently confirmed to be of lymphoid lineage, mostly of B-cell and occasionally of T-cell phenotype $[1,3,5,10,11,15,16]$. Some investigators proposed that the lymphocyteendothelial cell homing mechanism, including deficiency of homing receptors CDI la/ CD18, may be responsible for settling of the neoplastic cells in the small blood vessels [5, $6,10,15]$. In our case, the lymphoid lineage and the B-cell phenotype were confirmed.
The vascular occlusion of the involved organs together with the general effects of malignancy is responsible for the variation of the clinical presentation of ALCL. The initial clinical manifestations of ALCL are related to skin and CNS involvement in $75 \%$ of cases [6]. In our case, the main manifestations were hepatosplenomegaly, anaemia, and disturbed liver function tests. Our patient died 3 months after the histological diagnosis. This coincides with the findings of Domizio et al. [6], who reviewed 101 cases with ALCL and reported a median survival of 5 months from the date of clinical presentation.

We diagnosed ALCL from the liver and bone marrow biopsies. As far as we know and according to the available literature, liver and bone marrow biopsies have never been reported as being primary sites of ALCL. However, some authors $[1,4,9,10]$ found in autopsy cases hepatic and bone marrow involvement as part of dissemination of ALCL.

\section{References}

1 Al-Chalabi A, Sivakumaran M, Holton J, West KP, Wood JK, Abbott RJ: A case of intravascular malignant lymphomatosis (angiotropic lymphoma) with raised perinuclear antineutrophil cytoplasmic antibody titres: A hitherto unreported association. Clin Lab Haematol 1994; 16:363-369.

2 Ben-Ezra J, Sheibani K, Kendrick FE, Winberg CD, Rappaport H: Angiotropic large cell lymphoma of the prostate gland: An immunohistochemical study. Hum Pathol 1986; 17:964-967.

3 Bhawan J, Wolff SM, Ucci AA, Bhan AK: Malignant lymphoma and malignant angioendotheliomatosis: One disease. Cancer 1985;55: 570-576.
4 Chu P, Costa J, Lachman MF: Angiotropic large cell lymphoma presenting as primary adrenal insufficiency. Hum Pathol 1996;27:209211.

5 D'Agati V, Sablay LB, Knowles DM, Walter L: Angiotropic large cell lymphoma (intravascular malignant lymphomatosis) of the kidney: Presentation as minimal change disease. Hum Pathol 1989;20:263268.

6 Domizio P, Hall PA, Cotter F, Amiel S, Tucker J, Besser GM, Levison DA: Angiotropic large cell lymphoma (ALCL): Morphological, immunohistochemical and genotypic studies with analysis of previous reports. Haematol Oncol 1989;7:195206.
7 Dunphy CH: Primary cutaneous angiotropic large-cell lymphoma in a patient with acquired immunodeficiency syndrome. Arch Pathol Lab Med 1995;119:757-759.

8 Kamesaki H, Matusui Y, Ohno Y, Amano H, Imanaka T, Takahashi Y, Kobashi Y, Kawami K, Kita K: Angiocentric lymphoma with histological features of neoplastic endotheliomatosis presenting with predominant respiratory and haematologic manifestations: Report of case and review of the literature. Am J Clin Pathol 1990;94:768-772. 
9 Kitagawa M, Matsubara O, Song SiY, Kurashima C, Okeda R, Kasuga $\mathrm{T}$ : Neoplastic angioendotheliomatosis: Immunohistochemical and electron microscopic findings in three cases. Cancer 1985;56:1134-1143.

10 Lakhani SR, Hulman G, Hall JM, Slack DN, Sloane JP: Intravascular malignant lymphomatosis (angiotropic large cell lymphoma): A case report with evidence for $\mathrm{T}$-cell lineage with polymerase chain reaction analysis. Histopathology 1994; 25:283-286.

11 Molina A, Lombard C, Donlon T, Bangs CD, Dorman RF: Immunohistochemical and cytogenetic studies indicate that malignant angioendotheliomatosis is a primary intravascular (angiotropic) lymphoma. Cancer 1990;66:474-479.
12 Nishikawa K, Sekiyama S, Suzuki T, Ito Y, Matsukawa W, Tamai $\mathrm{H}$, Yoshida F, Fukatsu A, Matsuo S, Shigematsu H: A case of angiotropic large cell lymphoma manifesting nephrotic syndrome and treated successfully with combination chemotherapy. Nephron 1991;58:479482.

13 Pfleger L, Tappeiner J: Zur Kenntnis der systemisierten Endotheliomatose der cutanen Blutgefässe (Reticuloendotheliose?). Hautarzt 1959;10:359-363.

14 Prayson RA, Segal GH, Stoler MH, Licota AA, Tubbs RR: Angiotropic large-cell lymphoma in a patient with adrenal insufficiency. Arch Pathol Lab Med 1991;115:1039-1041.
15 Stepp N, Schuler G, Romani N, Geissler D, Gattringer C, Burg G, Bartram CR, Fritsch P: 'Intravascular lymphomatosis' (angioendotheliomatosis): Evidence for a T-cell origin in two cases. Hum Pathol 1990;21:1051-1058.

16 Stroup RM, Sheibani K, Moncada A, Purdy J, Battifora H: Angiotropic (intravascular) large cell lymphoma: A clinicopathologic study of seven cases with unique clinical presentation. Cancer 1990;66:1781-1788.

17 Wick MR, Banks PM, McDonald TJ: Angioendotheliomatosis of the nose with fatal systemic dissemination. Cancer 1981;48:2510-2517. 